\title{
CORRUPTION AND CRIME: UPSHOT ON THE STANDARD OF EDUCATION IN NIGERIA (CASE STUDY OF IMO STATE UNIVERSITY, OWERRI)
}

\author{
Opara Samuel E. ${ }^{1 *}$, Ihenetu Stanley $\mathbf{C}^{2}$., Urenyere R. $\mathbf{U}^{3}$. and Ihenetu Francis $\mathbf{C}^{4}$. \\ * 1,2 National Teachers Institute Kaduna, Nigeria, ${ }^{3}$ Alvan Ikoku College of Eduation, Owerri Imo state, \\ ${ }^{4}$ Imo State University Owerri, Nigeria
}

*Corresponding author: -

Email ID - ihenetustanley@yahoo.com

\begin{abstract}
: -
The quality and standard of education in Nigeria is one of the most pressing subjects in the minds of Nigerians who value education as far as education is concerned. Inferable from the escape clauses found in the educational arrangement of Nigeria today. Like, silly alumni, absence of legitimate educational direction on understudies and educators, deficient norm and accessibility of educational offices, arrangement of inadequate educational framework, degenerate educational personals or expert and so forth In any case, there are a few educational wrongdoings and debasement that militate against the achievement and acknowledgment of the ideal norm of training in Nigeria. A portion of these violations are pay off, cultism, drug misuse, lewd behavior/indiscrimination, assessment misbehavior from staff and understudies separately, theft of assets and so forth Consequently, in this undertaking, the specialist is examining about the falling norm of instruction because of wrongdoing, the different kinds of wrongdoing found in the educational framework and proffered answer for a decrepit educational framework. Despite the fact that, checking these educational wrongdoings and defilement should be an aggregate obligation of the guardians, educators, strict pioneers, specialists of the establishments just as the public authority. From the result obtained in this study, the Chi-square value calculated is greater than expected (critical), therefore the null hypothesis was rejected and conclude that the low standard of education is as a result of crimes and corruption in the sector.
\end{abstract}

Keyword: - Crime, Corruption, Nigeria, School.

\section{(c) $\$(1)$}




\section{INTRODUCTION}

One of the greatest threats to education, social, economic and political development of any society or nation is corruption. Therefore, the challenges of corruption remain a major devastating issue facing Nigeria. This has become a cankerworm that has eaten deep into the fabrics of our system. The United Nation Global Programme (PAC) defines it as "Abuse of power for private gain". The transparency international characterizes it as "The maltreatment of depended power for private increase". The World Bank anyway characterizes debasement as the maltreatment of office for private addition. Public office is manhandled for private increase when an authority, acknowledges, requests or coerces a payoff to accomplish something for childish reason (Blumber, 2009).

Given the following definitions therefore, corruption connotes any behaviour that deviates from an establish norm or what ought to be with regards to public trust. The problem of education is a result of the neglect which the sector suffered from the 1980c leading to the gradual erosion of the status quo of the system (Akanni and Odofin, 2015). These things include inadequate funding, lack of teaching tools, outdated lecture hall or poor lecturing condition of the environments, poor numerations, acute shortage of manpower and half-baked professionals for the job. These all have led to the fallen standard of education in Nigeria (Akaranga and Ongong, 2013). Nowadays, students spend most of their time watching television, playing video games, listening to music, going to clubs and the present calamity of bet-naija, naira bet, social media addiction like Facebook, Whatsapp etc. which prevent them from reading, dedication to studies, punctuality to duty and on the part of the teachers has also contributed to the fall in the standard of education.

Lack of care and attention on the side of parents to their children's education is another factor. All they put their attention is in their career and money making, leaving the motivation to the house maids. As a result, the children's projects, homework are left in the hands of housemaid that may have little or no knowledge of the things that are meant to be in order to be a good educators or teachers (Anzene, 2014).

- Corrupt officers/professional in the field of education always contributes to these effects by the misappropriation or misuse of institutions funds and yet they still go unpunished. To revive the educational sector, all these should be considered factor for amendment, reorientation and resuscitation of what ought to be seen, done and valued (Akaranga and Ongong, 2013).

- Staff numeration should also be looked into as well as a good percentage of her budget should be given to education. If both the government, parents and teachers should live up to their responsibility. Then and only by that can Nigeria reach great height and be among the first twenty countries by 2030 .

\section{Statement of the Problem}

This research seeks to determine to what extent crime has and corruption affected the quality and standard of education in Nigeria using Imo State University as a mirror. And what types of crimes are evidently seen having looked at our problem in the educational system that has led to the gradual rosining of the system. The research thus also seeks to know if these problems can be resuscitated from its dilapidated state that has led to the fall in the standard of education in Nigeria.

\section{Purpose of the Study}

The purpose of the study is to give us an insight into the following:

i. How crime and corruption in the education sector has brought the present sub-standard education in Nigeria.

ii. How the result of sub-standard education has affected youth development in Nigeria.

iii. It also seeks to give good and positive suggestions on how to curb the menace of crime and corruption in the educational sector in Nigeria.

\section{Research Hypothesis}

i. Is there any significant relationship between the effect of crime and corruption and the standard of education in Nigeria? Hi: There is a significant relationship between the effect of crime and corruption and the standard of education.

ii. Is there any significant relationship between the result of sub-standard education and the development of youth? Hi: There is a significant relationship between the result of sub-standard education and development of youth.

iii. Is there any significant relationship between curbing the crimes and corruption on the standard of education?

Hi: There is a significant relationship between curbing the crimes and corruption on the standard of education.

\section{Significance of Study}

Having stated the research hypothesis, it is therefore pertinent that people note the importance of this academic exercise which are as follows:

To bring awareness to the ignorant mind of citizens the proper sense of what education ought to be like. This can help reduce some of the vices seen in the educational sector like bribery, molestation and assault especially in tertiary institution and enable students know their fundamental human rights. The study is important because it shall proffer critical appraisal of the nature of crimes and corruption in Nigeria as they directly or indirectly affect the standard and ethics of education. It shall thus provide significant information for the government and other experts in the educational sector to curb most of these inadequacies found within the educational environ.

\section{Explication of Terms}

i. Crime: Crime can be defined as the acts and conditions that violate societal norms and values. According to the Oxford Learners Dictionary, crime means an activity that involves breaking the law. 
ii. Corruption: can be defined to be anything that connotes a dishonest behaviour. According to Oxford Advance Learner Dictionary it means a dishonest behaviour or illegal behaviour especially from people.

iii. Sub-Standard: In authority this ordinarily means anything not up to standard by the Oxford Advanced Learners Dictionary it means something not as good as normal.

iv. Appraisal: This means a judgment of the value and performance.

v. Menace: A thing that will cause serious damage, harm or danger.

vi. Curb: To restrain, to remove, to filter or control.

\section{Conceptual Framework \\ Concept of Crime}

Crime is as old as mankind. According to the Holy Bible, man disobeyed God by eating the fruit that God instructed that not to eat. Therefore, crime can be seen as an activity that involves breaking the law (Duffy and Gillig, 2004). The Oxford Dictionary defines crimes simply as "An action or omission which constitutes an offense and are punishable by law. Crimes are forms of evil, wicked, criminal action or behaviour in the society (Akaranga and Ongong, 2013).

Crimes are those acts and conditions that violate societal norms and values. Judges and lawmakers are influenced by these norms and values when they define what crime is and make recommendation about suitable punishment. But the truth is that, if a person is found engaged in act of behaviour that are considered to be harmful to society they could be found guilty of committing a crime (Greebberg, 2001). Crimes are generally presented in criminal court and some that are convicted of a crime may be forced to pay fines, and may also leave their personal freedoms privilege by being sentenced to jail or imprisonment. Crime may be viewed from various perspective with definitions put forth by various jurist or criminology on sociologist from time to time.

As Public Wrong: Sir William Black defines crimes in two ways, in his work. First, "As an act committed or omitted in violation of public law forbidding or commanding it". At a second stage, Black Stone modified his definition "As violation of public right and duties due to the whole community (Hertjen, 1992).

As Moral Wrought: Rafaela Garofalo defines crime in the following words: "Crime is an immoral and harmful act that is regarded as criminal by public opinion". In this definition Garofalo says that crimes are those acts, which no civilized society can refuse to recognize as criminal and are repressible by punishment (Raymond and Shawn, 2001).

As Conventional Wrong: Edwin Sutherland defines crime in terms of criminal behaviour as "Criminal behaviour is behaviour in violation of criminal laws". No matter what the degree of immorality or indecency of an act, it is not a crime unless prohibited by law.

As Social Wrong: John Gillin defines crimes as "An act that has been shown to be actually harmful to society or that is believed to be socially harmful by a group of people that place such act under the ban of positive penalties (Kopko, 2007).

\section{Types of Crime}

There are many different crimes, and what exactly constitute a crime may vary from state to state. In general, crimes may be categorized into four broad categories. These categories are personal crimes, property crime, inelautive crimes, and statutory crimes.

Persona Crimes: are most commonly generalized as violent crime that causes physical, emotional, or psychological harm to the victim (Turner et al., 2006). These crimes are offensive against the person, and can include but are not limited to:

$>$ Assault and Battery: Assault alludes to the deliberate making of a sensible fear of mischief. At the end of the day, attack is a circumstance which one individual makes someone else dread being hurt. Threatening behavior are most generally viewed as two unmistakable individual violations, albeit numerous states do consolidate the two wrongdoings into the one wrongdoing known as "threatening behavior".

$>$ Battery: alludes to the unapproved use of power against someone else's body. This outcomes in hostile contacting, or genuine actual injury. As some purview characterize attack as endeavored however bombed battery, battery accuses are regularly gathered of attack to shape the single changes of threatening behavior.

$>$ False Imprisonment: bogus detainment alludes to one individual coercively controlling someone else without wanting to with a danger of being truly harmed or slaughtered. Any individual, who deliberately limits someone else's opportunity of development without their assent, might be obligated for detainment.

$>$ Kidnapping: abducting is characterized as the diverting or control of an individual forcibly or double dealing, without that individual's assent. As such, abducting is the seizure and detainment of an individual without their assent, while meaning to divert the individual sometime in the future, hold the individual for deliver and so on

$>$ Homicide: Homicide incorporates violations, for example, first and second degree murder, compulsory homicide and vehicular manslaughter.

$>$ Rape: Rape likewise includes a legally defined sexual assault and rape.

$>$ Property related misconduct: Property wrongdoing or offenses against property, don't really includes the damage of someone else. Or maybe, these violations include obstruction with someone else's entitlement to utilize or make the most of their own property. A few instances of property related misdemeanors incorporate however not restricted to. 
$>$ Theft: (Larcency) alludes to a sort of robbery where an individual takes someone else's property and diverts it, with the plan to for all time characterize the lawful proprietor of their property.

$>$ (Burglary) is known as robbery forcibly, and may likewise be viewed as an individual wrongdoing as it regularly brings about physical and mental damage.

$>$ (Robbery) happens when an individual breaks and goes into a home or building, meaning to carry out a wrongdoing. This wrongdoing is by and large robbery, in spite of the fact that attack or pyromania may likewise comprise thievery.

$>$ Arsen: This is the resolved and noxious consuming or hurting of another people property or structures (Richardson and Budd, 2003; Raymond and Shawn, 2001; Anzene, 2014).

$>$ White Collar Crimes: (Misappropriation): alludes to a kind of white wrongdoing where an individual depended with the accounts of someone else or business wrongfully takes that cash for their very own utilization.

$>$ (Fraud) is another illustration of middle class wrongdoing, property related misconduct, since it is the creation, consideration, fabrication or impersonation of any record with purpose to swindle someone else of their property.

$>$ (Robbery): This can be alluded as middle class wrongdoing discovered generally in scholarly establishment were one copies a book or scholastic material to repeat it and after which attribute it to himself as the writer of the work to sell for his or by and by pick up.

$>$ False Pretenses: False misrepresentations allude to a blend of extortion and larcency, wherein an individual distorts to acquire the property of another.

$>$ Receipt of Stole Goods: It's a wrongdoing to get or buy property that you know or accept to be taken, or in any case got through burglary (Raymond and Shawn, 2001; Anzene, 2014).

Incholate Crimes or Incomplete: refers to violations that were started yet not brought to finish. An individual would have to make a considerable stride towards finishing a wrongdoing, instead of basically meaning to perpetrate wrongdoing. A couple of illustration of incholate violations include:

$>$ Attempted wrongdoings, for example, endeavored burglary, endeavored murder, and so on

$>$ Solicitation: violations including mentioning, asking, employing, directing, or urging another person to perpetrate a wrongdoing.

$>$ Conspiracy; violations including different entertainers meeting up to participate in crime.

Legal Crimes are infringement of explicit state or government status. They may include either property offenses or individual offenses. Instances of such violations are: Alcohol related wrongdoings, for example, selling of liquor to a minor, prohabitation of contrabands like Indian hemp, and so on (Akanni and Odofin, 2015)

\section{Concept of Corruption}

The word or definition "Corruption" has demonstrated dangerous especially in formal and authoritative archives. The UNDP Anti-corruption practice Note of 2004, alluding back to a paper affirmed by the Executive Committee in 1998, characterizes corruption as: "The abuse of public influence, office, or authority for private advantage through pay off, blackmail, influence hawking, nepotism, extortion, speed cash or misappropriation. Agreeing (5th Edition) corruption is unscrupulous or unlawful conduct, particularly of individuals in power utilizing their influence to do deceptive or illicit things as a trade-off for cash or to pick up a bit of leeway. The World Bank 1997 said corruption has to do with "The abuse of public workplaces for private additions".

Despite the fact that corruption is regularly viewed as a wrongdoing of government and community worker, it additionally wins in the private area (UNDP, 2010). Public office is abused for private increases when an official acknowledges, requests, or urges a payoff. Public office can likewise be abused for individual advantages regardless of whether no pay off happens, through support and nepotism. The Independent Corrupt Practice Commission (ICPC) Act (2000) segment 2 expresses that "Corruption essentially connotes inappropriateness and incorporates all types of unforgivable, rude and notorious lead in the presentation of some official and non-official duties. This implies any demonstration, which leaves any ordinary cultural practices (Blumber, 2009).

\section{Factors that Influence Students to Commit Crime}

A few factors influence wrongdoing and viciousness. These incorporate family factors, parenting style, party, peer gathering, drug, alcohol abuse and economic factors.

\section{Family Factors}

The family assumes a significant part in forming the conduct of students towards culpability. Students who are essential for broken homes in some cases feel baffled and regularly show conduct issues. These conduct issues can be seen through indignation, troublesome conduct and animosity. The mix of these prompts' criminal conduct and much of the time, little youngsters who partake in gathering based culpable may have lived in family where family individuals are engaged with crime. Through family inclusion, the possibility of wrongdoing becomes standardize (Blumber, 2009).

\section{Parenting Style}

Tolerant guardians are liberal and aloof in their parenting, and now and again accept that the most ideal approach to exhibit their affection for young adult students is to concede every one of their desires. Lenient guardians don't see themselves as dynamic members in forming their youngster's activity and as such don't prefer to state no or frustrate these kids. These students are bound to be requesting and they can do anything or go to any length to get what they need (Hertjen, 1992). 


\title{
Social Factor
}

Flimsiness inside the network likewise shapes the conduct of the students. The flimsiness of a network can be followed to political savagery, social brutality, wrongdoings, for example, commandeering, hijacking, assault, house breaking, and silly executing gangsterism and so forth Such people group may urge the student to be forceful and wind up accepting that brutality is the best way to address issue (Hertjen, 1992).

\section{Peer Influence}

Peer influence is generally critical in forming the conduct of the understudies. Peer pressure is an age-long plaque that overwhelmingly influences youngsters and be all in all an affecting factor in carrying out wrongdoings. Peer pressure control different teenagers into circumstance in which they feel it is highly unlikely out. When there are then again approaches to blacklist wrongdoings and other anti-social practices (Hertjen, 1992).

\section{Economic Factor}

Economic hardship influences youngsters in a few manners and these can have an immediate or circuitous impact on peer connections. For instance, youngsters who experience destitution are probably going to live in denied regions and in low quality lodging. In these territories, wrongdoing level and the dread of exploitation are high and youngsters may look to secure themselves via conveying weapons and shaping gatherings like cultism that urge them to grow wild awful practices, arrogances, eagerness for cash and so forth which the develop with or without limit (Greebberg, 2001).

\begin{abstract}
Alcohol/Drug Abuse
Alcohol and Drug admission prompts more significant levels of culpable and high-hazard practices among understudies. Drinking consistently is probably going to have impact on school participation and execution, which thusly increments other danger factors. Youngsters who drink in overabundance are bound to confess to being engaged with savage episodes or become luxurious with what is being given by their folks or direction (Greebberg, 2001). Once in a while they like to figure out their bombed courses with their instructors or talks as opposed to coming to class to learn due with the impact of alcohol/drug abuse. Most a times they get dependent on a flaw that they can't control it. This crushes their inward organs. A few kicks the bucket because of the impact of drug (hard drugs) particularly, some endure mental issues or mental hindrance. These can make the standard a school quitter and hence some would need to extort or scare their instructors or teachers for better scores are test and assessment (Richardson and Budd, 2003).
\end{abstract}

\section{Causes of Crimes and Corruption in the Educational System}

The causes of corruption in the educational system can be identified as follows:

a. Collection of money from student to pass them by lectures.

b. Inadequate supply of material which encourage some private inducement for service to be rendered.

c. Cumbersome documentation systems which make room for manipulation and conclusion of relevant interest to deprive educational system of legitimate revenue.

d. Employing unqualified graduates who cannot readily teach and has no skills to impact on student.

e. Deliberate delays in the performance of official duties in other to get elicit gratification.

f. Delay in posting bill into ledger and acknowledge payment for personal gain and fair auditing in the educational sector.

g. Indecent dressing in the side of students and lectures. These also aid in the rise of sexual immorality and above/molestation for grades (Richardson and Budd, 2003).

\section{Consequences of Corruption in the Educational System}

As the prior investigation plainly illustrated, corruption is in reality a startling issue in Nigerian instructive framework. Public assets are regularly subjectively handles, utilized for private reason or saved in close to home records. In schools, understudies who don't give/have cash to pass are defrauded (Turner et al., 2006). Corruption in the instructive area has influenced the norm, where a graduated can't talk great English nor even compose a decent assertion has next to zero revenue in adapting again found in the well-known aphorism "last school na trick". Corruption has additionally impeded economic and instructive advancement in Nigeria. As indicated by the World Bank (1995) somewhere in the range of 1973 and 1993, around 200billion dollar was put resources into Nigeria with almost no profits. Schools, foundations are as yet the manner in which they are with no new development, old data are as yet given to understudies when innovation has assumed control over the world yet no books or data to carryout research.

\section{Theoretical Framework \\ Theories of Corruption \\ Public Choice Theory:}

This hypothesis examinations corruption at the degree of the person. It places that the individual is "A normally ascertaining individual who chooses to become degenerate when it's anticipating impediments". In their view, corruption is a purposeful demonstration dependent on normal computation of interests. In the investigation of advanced education, understudy corruption is a utilization of public decision hypothesis which will accordingly necessitate that the degenerate lead of the individual understudy be the core interest. Numerous investigations of deceiving conduct have surely offered to follow this way. Nonetheless, the primary issue with this methodology is that besides by expanding the expense of cheating, it gets hard to forestall cheating (Kopko, 2007). 


\section{Bad Apple Theory:}

Bad apple theories set that corruption is established in flawed human character and inclination toward crime. Individuals act corruptly on the grounds that they have wrong moral values, for example, voracity. Many trait corruption among understudies to absence of moral childhood and family foundation. Their idea of corruption additionally exhibits a membership to this view point in a profoundly strict way. Society, for example, Nigeria, it ought not to be an astonishment. Nonetheless, experimental examinations have indicated that morality works in the lives of understudies at two levels: explanatory and down to earth levels and that there are contrasts between these two. One investigation found that "The high pace of cheating showed by the understudies was not comprised with their communicated negative demeanor to cheating". Yet, most occasions they are compelled to cheat and afterward the cheat which is the handy angle (Salawu, 2003).

\section{Organization Culture Theories:}

This gathering of theories expects that corruption results from the psychological state ingrained in people by bunch culture and not from broken character or wrong morality.

Organization hypothesis tries to portray the conditions under which corruption may happen however can't represent why specific people - and no others - are degenerate. They essentially accept that "Individuals in organizations follow up on the specific elements of the organization" (Blaya, 2006). In applying organization hypothesis to cheating among understudies, Gallant and Drina, contended that it "Gave a heartier system: for the investigation of understudy deceiving issue by arranging it in "The setting of instructive foundation as an intricate organization influenced by individuals, time, and social powers". It thinks about instructive establishments as mind boggling organizations "On the grounds that various diverse sub-bunches are key to its working" and that perplexing organizations have on intrinsic propensity to endure (Ojukwu and Nwanna, 2015).

Clashing Moral Values Theories: This gathering of theories considers corruption at the full-scale level of the society. Individuals from this gathering find corruption in cultural standards and values which impact people act in a degenerate way. It emerges for the conflict of values associated with one's private and one's public job which requires the creation of a decision. The conflict is among values and standards which oversees commitments to close relations, for example, loved ones and those which administer official direct (Ojukwu and Nwanna, 2015).

\section{METHODOLOGY}

Research Design: The method in this study is descriptive survey. The survey method is based on face to face interviews, telephone interview, mails, interviews or questionnaires of past records for the purpose of extracting useful information. However, in this study the research employed only questionnaires and inspection of past records to obtain the necessary information.

\section{Area of Study:}

The research work was carried out in Imo State University, located in the heart Owerri, Imo State Capital in the South East of Nigeria.

\section{Population of Study:}

Imo State University has over 10,000 students comprising of regular students. The institution has been training students in Degree Programs.

\section{Sampling and Sampling Technique:}

A total of 200 students were selected as sample for the purpose of this study. These students were randomly selected and from the population and questionnaires were administrated to them.

\section{Research Instrument:}

The research employed the use of questionnaire for collecting the required data. The student questionnaires are divided into two sections, A and B.

Section A contains the general information and Section B is further divided into three parts 1, 2, and 3. Part one attempts to find out what their effects of corruption to the standard of Education in Imo State University, Owerri. Part two attempts to find out in what ways can crimes and corruption be curbed and what will be the result of curbing crimes and corruption in the entire education system. Part three attempts to find out the causes and the result of sub-standard education and development of youths. Each of these parts contains five questions which are: Strongly Agreed (SA), Agreed (A), Strongly Disagreed (SD), and Disagreed (D).

\section{Validation of Instrument:}

The questionnaires were administered to the respondents after the approval by the supervisor.

\section{Method of Data Collection:}

The data for this research work is both primary and secondary. The Primary data were gotten from the questionnaires administered to the sample drawn while the secondary data were from the internet and some textbooks. 
Data Analysis Techniques:

The analysis of the data collected for the research was the use of Tables and illustration.

\section{Method of Data Analysis:}

The research adopted Ch-Square contingency test. This was for the purpose of clarity of mind and of analysis, as well as simplicity of the result.

\section{DATA ANALYSIS AND RESULTS}

\section{Chi-Square Contingency Test}

The research adopted Chi-Square contingency test. This was for the purpose of clarity of mind and of analysis, as well as simplicity of the result. The equation is given.

$$
\mathrm{X}^{2}=\frac{\Sigma(\mathrm{O}-\mathrm{E})}{\mathrm{E}}
$$

Where $\mathrm{O}=$ Observed Frequency

$\mathrm{E}=$ Expected Frequency

The expected frequency $(\mathrm{E})$ is given as

$$
\mathrm{E}=\frac{\text { Row Total x Column Total }}{\text { Grand Total }}
$$

Reasons for using Chi-Square method was to:

To determine the discrepancy between observed frequency $(\mathrm{O})$ and expected frequency $(\mathrm{E})$.

To evaluate the nature of hypothesis testing, either accepting or rejecting the null $\left(\mathrm{H}_{0}\right)$ or the alternative $\left(\mathrm{H}_{1}\right)$ hypothesis. To justify the level of hypothesis testing either stated in terms of the research topic such as "Effect of crimes and corruption on the standard of education in Nigeria".

Note: The degree of freedom (df) in a distribution is the number of observations or values that are independent of each other, i.e. that cannot be deducted from each other. The degree of freedom is given by.

$\mathrm{Df}=(\mathrm{R}-\mathrm{I})(\mathrm{C}-\mathrm{I})$

Where $\mathrm{R}=$ Number of Rows of Observed Frequency in the table.

$\mathrm{C}=$ Number of Columns of Observed Frequency in the table.

\section{Presentation and Interpretation of Results}

The analysis and interpretation were done in order to deflect the objective for which the research was carried out. A total of 200 copies of questionnaires were distributed and returned after completion respondents. The results are presented in table 1-2 below.

\section{Test of Hypothesis}

Table 1a

Information for Respondents by Sex.

\begin{tabular}{|l|l|l|l|l|l|}
\hline Sex of Respondent & SA & A & SD & D & Total \\
\hline Male & 40 & 50 & 20 & 15 & 125 \\
\hline Female & 30 & 15 & 10 & 20 & 75 \\
\hline Total & 70 & 65 & 30 & 35 & 200 \\
\hline
\end{tabular}

To compute the expected frequencies, remember

That $\mathrm{X}^{2}=\frac{\Sigma(\mathrm{O}-\mathrm{E}) 2}{(\mathrm{E})}$ 
Where $\mathrm{E}=\frac{\text { (Row Total } \mathrm{x} \text { Column Total) }}{}$

Expected for Male $(\mathrm{SA})=\frac{125 \times 70}{200}=43.75$

Expected for Male $(A)=\frac{125 \times 65}{200}=40.63$

Expected for Male $(\mathrm{SD})=\frac{125 \times 30}{200}=18.75$

Expected for Male $(D)=\frac{125 \times 35}{200}=21.88$

Expected for Female $(\mathrm{SA})=\frac{75 \times 70}{200}=26.25$

Expected for Female $(A)=\frac{75 \times 65}{200}=24.38$

Expected for Female $(\mathrm{SD})=\frac{75 \times 30}{200}=11.25$

Expected for Female $(D)=\frac{75 \times 35}{200}=13.13$

Table 1b: The Chi-Squared $\left(\mathrm{X}^{2}\right)$ table for the observed and expected frequencies is given in table $1 \mathrm{~b}$ below.

\begin{tabular}{|c|c|c|c|c|}
\hline Observed (O) & Expected (E) & O-E & $(\mathrm{O}-\mathrm{E})^{2}$ & $\begin{array}{l}(\mathrm{O}-\mathrm{E})^{2} \\
\mathrm{E}\end{array}$ \\
\hline 40 & 43.75 & -3.75 & 14.06 & 0.32 \\
\hline 50 & 40.63 & 9.37 & 87.79 & 2.16 \\
\hline 20 & 18.75 & 1.25 & 1.56 & 0.08 \\
\hline 15 & 21.88 & -6.88 & 47.33 & 2.16 \\
\hline 30 & 26.25 & 3.75 & 14.06 & 0.54 \\
\hline 15 & 24.38 & -9.38 & 87.98 & 3.61 \\
\hline 10 & 11.25 & -1.25 & 1.56 & 0.14 \\
\hline 20 & 13.13 & 6.87 & 47.19 & $\begin{array}{l}3.59 \\
12.60\end{array}$ \\
\hline
\end{tabular}

$\mathrm{X}^{2}=\frac{\Sigma(\mathrm{O}-\mathrm{E}) 2}{(\mathrm{E})}$

The degree of freedom (df) is given as

Df $=(\mathrm{R})(\mathrm{C}-\mathrm{I})$

$=(4-1)(2-1)$

$=3 \times 1$

$: \mathrm{df}=3$

From our $\mathrm{X}^{2}$ - table, the table $\mathrm{X}^{2}$ at df of 310.05 level of significance is 7.815 . Based on the fact that the calculated values are greater, we therefore reject the null hypothesis and accept the alternative hypothesis. We conclude that the declining standard of education in Owerri is as a result of crimes and corruption on the standard of education.

Table 1c: The Chi-square Analysis of Effect of Crime and Corruption on the Standard of Education

\begin{tabular}{|l|l|l|l|l|l|l|l|l|l|}
\hline $\begin{array}{l}\text { Sex of } \\
\text { respondent }\end{array}$ & SA & A & SD & $\mathbf{D}$ & Total & $\begin{array}{l}\mathbf{X}^{\mathbf{2}} \\
\mathbf{C r i t i c a l}^{2}\end{array}$ & $\begin{array}{l}\mathbf{X}^{\mathbf{2}} \\
\text { Calculated }^{-}\end{array}$ & Df & Decision \\
\hline Male & 40 & 50 & 20 & 15 & 125 & & & & Significance \\
\hline Female & 30 & 15 & 10 & 20 & 75 & 7.815 & 12.60 & 3 & \\
\hline Total & 70 & 65 & 30 & 35 & 200 & & & & \\
\hline
\end{tabular}

Table 2a: Information of Respondents by Age

\begin{tabular}{|l|l|l|l|l|l|}
\hline Age & SA & A & SD & D & Total \\
\hline $16-24$ & 40 & 50 & 25 & 20 & 135 \\
\hline $25-35$ & 30 & 10 & 15 & 10 & 65 \\
\hline Total & 70 & 60 & 40 & 30 & 200 \\
\hline
\end{tabular}

$$
\begin{aligned}
\text { Df } & =(\mathrm{R}-\mathrm{I})(\mathrm{C}-\mathrm{I}) \\
& =(4-1)(2-1) \\
& =3 \times 1 \\
& =3
\end{aligned}
$$


Expected for Age $16-24(\mathrm{SA})=\frac{135 \times 70}{200}=47.25$

Expected for Age 16-24 (SD) $=\frac{135 \times 40}{200}=27.00$

Expected for Age $16-24(D)=\frac{135 \times 30}{200}=20.25$

Expected for Age $25-35(\mathrm{SA})=\frac{65 \times 70}{200}=22.75$

Expected for Age $25-35(A)=\frac{65 \times 60}{200}=19.50$

Expected for Age $25-35(\mathrm{SD})=\frac{65 \times 40}{200}=13.00$

Expected for Age $25-35(D)=\frac{65 \times 30}{200}=9.00$

Table 2b: The Chi-Square $\left(\mathrm{X}^{2}\right)$ table for the observed and expected frequencies is given in the table below.

\begin{tabular}{|l|l|l|l|l|}
\hline Observed (O) & Expected (E) & O-E & $(\mathbf{O}-\mathbf{E})^{\mathbf{2}}$ & (-E) $)^{\mathbf{2}}$ \\
\hline 40 & & & & $\mathbf{E}$ \\
\hline 50 & 47.25 & -7.25 & 52.56 & 1.11 \\
\hline 25 & 40.50 & 9.50 & 90.25 & 2.23 \\
\hline 20 & 27.00 & -2.00 & 4.00 & 0.15 \\
\hline 30 & 20.25 & -0.25 & 0.06 & 0.003 \\
\hline 10 & 22.75 & 7.25 & 52.56 & 2.31 \\
\hline 15 & 19.50 & -9.50 & 90.25 & 4.63 \\
\hline 10 & 13.00 & 2.00 & 4.00 & 0.31 \\
\hline
\end{tabular}

$\mathrm{X}^{2}=\frac{\Sigma(\mathrm{O}-\mathrm{E}) 2}{(\mathrm{E})}$

$=10.853$

Table 2c: The Chi-square Analysis, the result can be represented in the below.

\begin{tabular}{|l|l|l|l|l|l|l|l|l|l|}
\hline Age & SA & A & SD & D & Total & $\begin{array}{l}\mathbf{X}^{2} \\
\text { Critical }\end{array}$ & $\begin{array}{l}\mathbf{X}^{2} \\
\text { Calculated }\end{array}$ & Df & Decision \\
\hline $16-24$ & 40 & 50 & 25 & 20 & 135 & 7.815 & 10.853 & 3 & Significance \\
\hline $25-35$ & 30 & 10 & 15 & 10 & 65 & 7.815 & 12.60 & 3 & \\
\hline Total & 70 & 60 & 40 & 30 & 200 & & & & \\
\hline
\end{tabular}

Based on the fact the calculated value is greater, we therefore reject the null hypothesis and conclude that the low standard of education is as a result of crimes and corruption in the sector.

Data Analysis

The tables above are used to analyze the information provided by the respondents in part one of section is of the questionnaire. 125 were male 75 were female. For age of respondents, 135 fall between the ages of 25-35.

Table 1c and 2c showed that the calculated value is greater than the critical value and decision was to reject the null hypothesis and accept the alternative hypothesis. The table below shows the information provided by the respondents in each of the items in the questionnaire. 
Table 3: Different respond from respondents

\begin{tabular}{|c|c|c|c|c|c|}
\hline Statement & SA & $\mathbf{A}$ & SD & D & Total \\
\hline $\begin{array}{l}\text { Do you agree that student's performance as below average is a result of } \\
\text { crimes and corruption? }\end{array}$ & 120 & 60 & 5 & 15 & 200 \\
\hline $\begin{array}{l}\text { Do you agree that sub-standard education is due to unqualified } \\
\text { personnel's/staff in the sector? }\end{array}$ & 80 & 60 & 20 & 40 & 200 \\
\hline $\begin{array}{l}\text { Do you agree that crimes and corruption in higher institutions aid truancy, } \\
\text { cheating and deviant behaviours? }\end{array}$ & 135 & 55 & 4 & 6 & 200 \\
\hline $\begin{array}{l}\text { Do you agree that students prefer to bribe their ways through (sorting), rather } \\
\text { than burning mid-night candles to merit their degree? }\end{array}$ & 100 & 60 & 20 & 20 & 200 \\
\hline $\begin{array}{l}\text { Do you agree that with the level of bribery (sorting), children from poor } \\
\text { home will not be able to go to school in future? }\end{array}$ & 150 & 140 & 0 & 10 & 200 \\
\hline $\begin{array}{l}\text { Do you agree that the government is the major cause of sub-standard } \\
\text { education in Nigeria? }\end{array}$ & 150 & 40 & 1 & 9 & 200 \\
\hline $\begin{array}{l}\text { Do you agree that Nigeria economy will develop with the present standard } \\
\text { of education? }\end{array}$ & 0 & 0 & 150 & 50 & 200 \\
\hline $\begin{array}{l}\text { Do you agree with scholar's opinion that Nigeria certificate are respected } \\
\text { internationally with kind of education we have? }\end{array}$ & 5 & 5 & 120 & 70 & 200 \\
\hline $\begin{array}{l}\text { Do you agree that Nigeria graduates will compete favourably internationally } \\
\text { if given proper and good quality education? }\end{array}$ & 100 & 80 & 5 & 15 & 200 \\
\hline $\begin{array}{l}\text { Do you agree that in the nearest future, private institutions will take over the } \\
\text { education system in Nigeria due to sub-standard education in the country? }\end{array}$ & 110 & 60 & 10 & 20 & 200 \\
\hline Do you agree that crimes and corrupt individuals are sentenced to jail? & 100 & 50 & 20 & 30 & 200 \\
\hline $\begin{array}{l}\text { Do you agree that crimes and corruption can be curbed if computer/data base } \\
\text { control system is introduced? }\end{array}$ & 10 & 20 & 120 & 50 & 200 \\
\hline $\begin{array}{l}\text { Do you agree that if staff salaries are increase and bursary is paid to students } \\
\text { will stop crimes and corruption on campuses? }\end{array}$ & 80 & 60 & 20 & 40 & 200 \\
\hline $\begin{array}{l}\text { Do you agree that making laws and leading by example by the authorities } \\
\text { themselves is the only way to stop crimes and corruption? }\end{array}$ & 150 & 35 & 5 & 10 & 200 \\
\hline $\begin{array}{l}\text { Do you agree that sacking all the existing staff in the education sector and } \\
\text { recruiting new hands into the system is the only way to stop crime and } \\
\text { corruption? }\end{array}$ & - & 10 & 150 & 40 & 200 \\
\hline
\end{tabular}

\section{DISCUSSION OF FINDINGS}

The finding revealed that some of the assumptions earlier discussed by different authors in the review of literature are true and if not properly handle the entire education system will surely collapse in the nearest future. The majority of the respondents believe that the government is the major cause of sub-standard education in Nigeria. It was also believed by the majority of the respondents that it corrupt individuals are sentenced to jail, the rate of crimes and corruption will reduce majority of the respondents also agreed that Nigeria economy cannot develop with the present standard of education and also if staff salaries are increased and bursary is given to student, the crime rate and corruption in higher institution will surely reduce.

\section{Recommendation}

After a critical and cautious investigation of the effects of crimes and corruption upsetting the education arrangement of Nigeria, the accompanying recommendation were made to help the public authority in the offer to destroy crime and corruption.

i. Adequate asset should be given by the public authority to effective implementation of certain strategies that will be good for the understudy and Nigeria.

ii. The government through the services of education should focus on the educational necessities of the understudy.

iv. Teachers and other staff pay rates should be paid immediately and be explored.

v. Admission into higher institutions of learning should be founded on legitimacy.

v. Corrupt people be it educators, understudy or other staffs trapped in the demonstration should be attempted and imprisoned to fill in as an impediment to others.

\section{Suggestion in for Further Research}

i. It is trusted that the consequence of this exploration work will encourage further work around there of human undertaking and consequently lead to the improvement of another and lively arrangement of education in Nigeria.

ii. If another compensation scale for teachers is checked on and executed, it will lessen their attention on gathering money from understudy. 


\section{Conclusion}

Investigation revealed that standard and quality of education will continue to depreciate if corrupt individuals caught in the act are not probed. It was also revealed that crime and corruption has affected educational standard in Nigeria and both the government and the student are responsible for it. If Nigeria as a country wishes to have a good and vibrant system of education, the government has a great role to play.

\section{REFERENCES}

[1].Akanni, O. O. and Odofin, B. (2015). Reducing Examination Malpractices in Nigerian Schools through effective Continuous Assessment (C.A) techniques as an alternative to one - short Examination in Osun State, Nigeria, American Journal of Educational Research, 2(1):91-101.

[2].Akaranga, S. I. and Ongong, J. J. (2013). The phenomenon of Examination Malpractice: An example of Nairobi and Kenyatta Universities. Journal of Education and Practice 4(18):87-9.

[3].Anzene, S. J. (2014). Trend in Examination Malpractice in Nigeria Development of Nigeria Asian Journal of Humanities and Social Sciences, 2(3):1-8.

[4].Blaya, C. (2006). "Climay violencia escolar. Un studio comparative entre Espanay Francia”,Revista de education, No. 339, Madrid, Ministry of Education.

[5].Blumber, A. (2009). Criminal Justice issues and ironies. New York: New view point.

[6].Duffy, M and Gillig, S. (2004). Teen gange: A global view. London: Greenwood Press.

[7].Greebberg, D. F. (2001). Time series analysis and crime rates. Journal of Quant. Criminal 17:291-327.

[8].Hertjen, C. A. (1992). Crime and Criminalization. New York: Holt and Winston.

[9].Kopko, K. (2007). Parenting style and adolescent. USA: Cornell University.

[10]. Ojukwu, M. O. and Nwanna, A. C. (2015). Influence of Insecurity of School Environment on the Behaviour of Secondary School Students in Isiala-Ngwa North and South Local Government Area of Abia State, Nigeria. International Journal of Education \& Literacy Studies, 3(4), $49-55$.

[11]. Raymond, P. and Shawn, D. (2001). Quantitative Criminology. Vol 17. No 4 Plenum Publishing Corporation.

[12]. Richardson. A. and Budd, T. (2003). Alcohol Crime and disorder: A Study of young adults. London: The home office.

[13]. Salawu, B. (2003). Sociology concepts and theories. Ibadan. Cresthill Publishers Ltd.

[14]. Turner, K., Hill. M., Stafford, A. and Walker, M. (2006). "How children from disadvantaged areas keep safe" in Health Education, Vol. 106, No. 6. 